\title{
Effect of cognitive and metacognitive learning strategies training on academic procrastination and self efficacy in students
}

\author{
Ezatollah Ghadampour $^{1 *}$ iD , Kobra Beiranvand ${ }^{2}$
}

1. Associate Professor in Educational Psychology, Department of Psychology, Faculty of Literature and Human Sciences, Lorestan University, Khorramabad, Iran

2. MS in Educational Psychology, Department of Psychology, Faculty of Literature and Human Sciences, Lorestan University, Khorramabad, Iran

Recieved: 4 Sep. 2018

Revised: 10 Mar. 2019

Accepted: 8 Apr. 2019

\section{Keywords}

Academic procrastination

Self-efficacy

Cognitive and metacognitive learning strategies

\section{Corresponding author}

Ezatollah Ghadampour, Associate Professor in Educational Psychology, Department of Psychology, Faculty of Literature and Human Sciences, Lorestan University, Khorramabad, Iran

Email: Ghadampour.e@lu.ac.ir

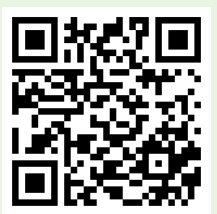

\section{Abstract}

Introduction: The procrastination is a common failure in self-regulation. Students who consider themselves efficient, use cognitive and metacognitive learning strategies more and make more effort to do their assignments. The aim of this study was to investigate the effect of cognitive and metacognitive learning strategies on academic procrastination and self-efficacy of students.

Methods: The research method was semi-experimental and its design was pretest, posttest with control group and follow-up stage. The statistical population comprised all middle school students in the city of Khorramabad, in the academic year of 2015-2016, among whom 30 students having academic procrastination (score $\geq 30$ ) were selected through the step random sampling method. Then, with semi-experimental method, the students were divided into two groups: exprimental (15 students) and control (15 students). The students in exprimental group received the training of cognitive and metacognitive learning strategies for 90-min eight sessions (once a week). The data were obtained by using the Academic Procrastination Questionnaire and General Self-efficacy Scale and the multi-variable covariance analysis (MANCOVA) was applied to analyze the data.

Results: The results showed that cognitive and metacognitive learning strategies training reduced significantly academic procrastination and increased self-efficacyy in the exprimental group towards the control group ( $\mathrm{P}>0.001)$. Also, this effect continued until the follow-up phase.

Conclusion: Based on the research results, it can be said the training of the cognitive and metacognitive learning strategies has a beneficial effect on decreasing academic procrastination and increasing self-efficacy among female students. 


\title{
تاثير آموزش راهبردهاى يادكيرى شناختى و فراشناختى بر اهمال كارى تحصيلى و خودكار آمدى دانش آموزان
}

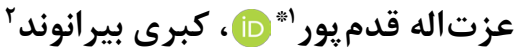

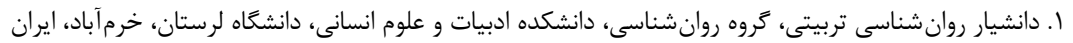

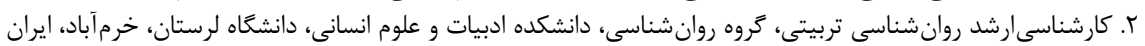

\section{aris}

مقلدمه: اهمال كارى صورتى شايع از شكست در خودتنظيمى است. دانشآموزانى كه خود را كارآمد مىدانند، از راهبردهاى شناختى و فراشناختى بيشترى استفاده مى كنند و براى انجام تكاليف تلاش بيشترى مى ورزند. هدف يزوهش رتش حاضر بررسى تاثير آموزش راهبردهاى يادكيرى خودتنظيمى بر اهمال كارى تحصيلى و خودكارآمدى در دانشى آموزان بود. روش كار: روش يزوهش حاضر، نيمه آزمايشى با طح بيش آزمون_يس آزمون و يِيخيرى همراه با گروه كنترل بود. جامعه يزؤهش شامل تمامى دانشآموزان دوره دوم متوسطه شهر خرمآباد در سال تحصيلى هو-\$وجا بودند، كه از ميان آنها • ب دانش آموز داراى اهمال كارى تحصيلى (نمره •r به بالا) به شيوه نمونه كيرى تصادفى مرحلهاى انتخاب و با شيؤ نيمه آزمايشى، در دو كروه آزمايش و كنترل (هر كروه ها نفر) گمارده شدند. آموزش راهبردهاى يادَّيرى شناختى و فراشناختى ري به مدت 1 جلسه •و دقيقهاى طى يك جلسه در هفته بر روى دانش آموزان كروه آزمايش انجام كرفت. دادهها با استفاده يرسشنامه هاى اهمال كارى تحصيلى و خودكارآمدى عمومى جمع آورى شد. از روش تحليل كواريانس جند متغيره و تك رك متغيره با نرمافزار SPS-18 جهت تحليل دادهها استفاده شد. يافته ها: نتايج حاصل از تحليل كواريانس نشان داد كه آموزش راهبردهاى يادكيرى شناختى و فراشناختى به طور معنادارى باعث كاهش اهمال كارى تحصيلى و افزايش خودكارآمدى در دانشآموزان گروه آزمايش نسبت به كروه كنترل

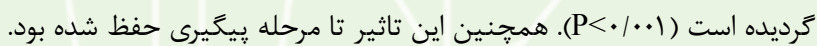
نتيجه كَيرى: بر اساس يافتهاى يزوهش مى توان كَفت آموزش راهبردهاى يادكيرى شناختى و فراشناختى در كاهش

$$
\text { اهمال كارى تحصيلى و افزايش خودكارآمدى دانش آموزان دختر مؤثر است. }
$$

دريافت: r اصلاح نهايى:

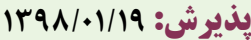
وازههاى كليدى

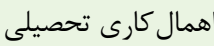

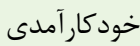
راهبردهاى يادكيرى شناختى و فراشناختى دانش آموزان

نويسنده مسئول عزتاله قدميور، كروه روانشناسى، دانشكده ادبيات و علوم انسانى، دانشخاه لرستان، خرمآباد، ايران ايميل:Ghadampour.e@lu.ac.ir

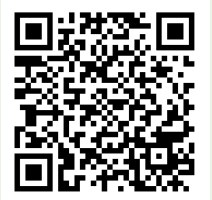

dol doi.org/10.30699/icss.21.3.31

مقدمه

دانشجويان است كه معمولا به صورت عدم انجام تكاليف و عدم مطالعه براى امتحان ديده مىشود (ז). دانشآموزان اهمال كار آمادگى براى امتحان را به شب يايانى موكول مى كنند و در نتيجه در زمان امتحان اضطراب شديدى را تجربه مى كنند. با توجه به زَزارش دانشآموزان، ميزان اهمال كارى آنها رابطه منفى معنادارى با عملكرد تحصيلىشان
اهمال كارى (Procrastination) به عنوان يك عادت رفتارى در نظر كرفته مى شود كه شيوع فراوانى در جوامع مختلف دارد و روند رشد آن رو به كسترش است. به كفته Moon و Illingworth اهمال كارى جلوههاى گوناگونى دارد اما متداول ترين نوع آن اهمال كارى تحصيلى است ( (). اهمال كارى تحصيلى يك رويداد شايع ميان دانشآموزان و 
خودتنظيمى علاوه بر راهبردهاى شناختى، در برگيرنده راهبردهاى فراشناختى نيز مىباشد. مفهوم فراشناخت نخستين بار توسط مطرح شد، وى فراشناخت را هرگَونه دانش يا كنش شناختى تعريف مى كند كه موضوع آن شناخت يا تنظيم شناخت است (9 (1). فراشناخت يكى از مؤثرترين مؤلفه هاى ييشبينى كننده در انجام تكاليف ييجيده به شمار

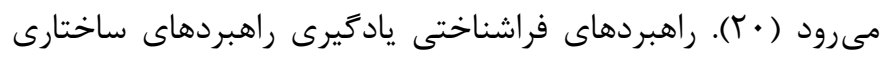
هستند كه به يادَيرنده اجازه استفاده از فراشناخت را در حل مسئله مى دهند. اين راهبردها شامل بررسى آگاهانه يادگيرى، طراحى و انتخاب راهبردها، بررسى پيشرفت يادگيرى، تصحيح اشتباهها، تحليل كارايى راهبردهاى شناختى يادگيرى و تغيير رفتارها در زمان لازم است ( I T Y (Y). راهبردهاى فراشناختى شامل سه راهبرد برنامه ريزى، كنترل و نظارت و نظمدههى مى باشد (IV). مطالعات متعددى نشان دادهاند كه خود-كار آمدى، با كاربرد راهبردهاى خودتنظيمى و راهبردهاى شناختى رابطهى مثبت دارد (سT، TY). تلاش و استقامت عملكرد دانش آموزان را در مواجهه با مشكلات افزايش مى رهند و احساس خودتنظيمى را بهبود مىبخشند و به آنها كمك مى كند تا خود كارآمدى بالقوه خود را رشد دهند (له). برخى از مطالعات نشان دادهاند كه بين خود كارآمدى و راهبردهاى يادكيرى عميق و همجنين خودتنظيمى با موفقيت

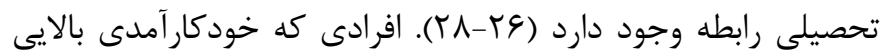
دارند، در مقايسه با كسانى كه باورهاى خودكارآمدى يايين دارند، از راهبردهاى شناختى و خودتنظيمى به ميزان بيشترى استفاده مى كنند Cleary و و Zimmerman در مطالعهاى دريافتند كه يكى از علل مهم نبود موفقيت تحصيلى، خودكارآمدى يايين است. آنان دريافتند مشكلات تحصيلى برخى از دانش آموزان، به علت به كار نبردن

راهبردهاى يادَيرى خودتنظيمى است (• (ץ). با توجه به مطالب كفته شده راهبردهاى ياد از جمله عواملى هستند كه بر اهمال كارى (9-A) و خود كارآمدى (II)،

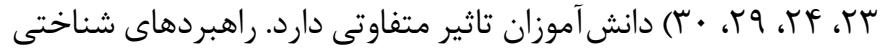
و فراشناختى به عنوان راهبردهاى يادگيرى خودتنظيمى تدابيرى هستند كه به يادگيرى و يادآورى كمك خواهند كرد، هر خند اين راهبردها قابل يادگيرى هستند ولى بعضى از ياد كيرندگان از عهدهى آن لن

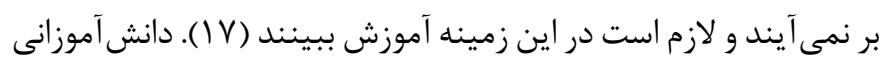
هم كه اهمال كارى دارند، در آغاز و همجنين در مداومت در ريخيرى هدف هاى تحصيلى شان ناتواناند، كه نمودى از ضعف در خودتنظيمى در آنها است. با آحاهى از راهبردهاى يادَيرى خودتنظيمى و تأثير آن بر عملكرد تحصيلى، دستاندر كاران تعليم و تربيت مىتوانند با در نظر گرفتن شيوههاى يادگيرى و راهبردهاى آن، هدفهايى قابل دسترس
دارد (זّ). Senécal و همكاران نشان دادند دانشآموزانى كه دلايل درونى براى درس خواندن دارند، به احتمال كمترى نسبت به آنهايى

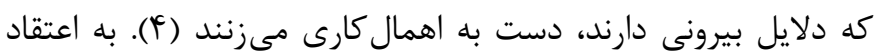

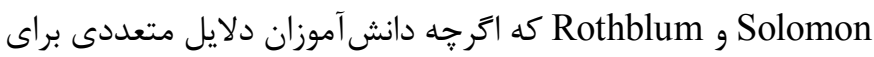

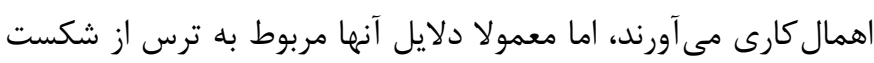

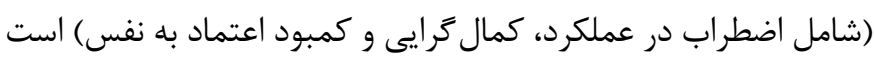
(ه). اهمال كارى صورتى شايع از شكست در خودتنظيمى است (9). Wolters بيشترى از اهمال كارى در تكاليفشان داشتند، كمتر از دانشجويان ديكر راهبردهاى شناختى و فراشناختى را مورد استفاده قرار مى دادند (V) كه از راهبردهاى يادگيرى شناختى و فراشناختى استفاده مى كنند، كمتر مرتكب اهمال كارى مى شوند (N). داشتن انخيزه، انتخاب هدف، كنترل عواطف و احساسات منفى، آغاز گرى، ڤشتكار، پايدارى به هنغام مواجهه با شكست، همكى مفاهيمى هستند كه مى توانند در ارتباط با تعلل و اهمال كارى نقشى منفى و كاهنده داشته باشند. مطابق با نظر Bandura يكى از عواملى كه بر اهمال كارى تاثير مى گذارد، خود كارآمدى است (9). خودكارآمدى عبارت است از ارزيابى خود شخص از توانايى هاى خود در ارتباط با فعاليتى خاص. خودكارآمدى منعكس كننده توانايى يادگيرندگان در برخورد با تكاليف جديد است

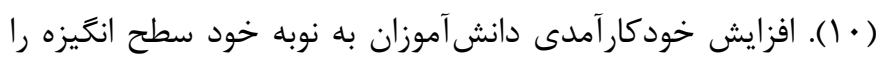
افزايش مى دهد (T I ). شواهد يزوهشى حاكى است دانش آموزانى كه خود را كارآمد مى دانند، از راهبردهاى شناختى و فراشناختى بيشترى استفاده مى كنند و براى انجام تكاليف تلاش بيشترى مىورزند (1). خودتنظيمى، سازهاى است كه از سال 199V از سوى Bandura طرح شد. مطالعه اوليه در اين زمينه، مبتنى بر خودتنظيمى به معناى عام كلمه بود كه زمينه هاى گوناگون فردى_خانوادگى و اجتماعى را مورد توجه قرار مى داد؛ ولى از دهه •ب19 ا، اين سازه در زمينه يادگيرى مطرح شد (r I). Oxford, راهبردهاى ياد كيرى خودتنظيمى را مجموعه فعاليتهاى خاص انجام شده توسط ياد گيرنده جهت يادگيرى آسانتر، سريع تر، لذتبخشتر، خودراهبرتر، مؤثرتر و قابل انتقال به موقعيت هاى

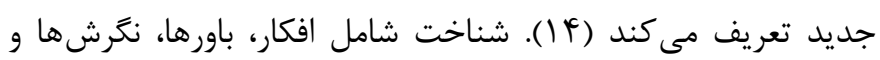
ارزشهايى است كه يك فرد آكاهانه درباره خودش، رفتارش و محيط ييرامونش دارد (ه (1). Pintrich (1991 (1) راهبردهاى شناختى را شامل راهبردهاى تكرار و مرور ذهنى، بسط و گسترش و سازمان دهى مى داند (ع). سازماندهى بهترين و كامل ترين نوع راهبرد يادگيرى است، در

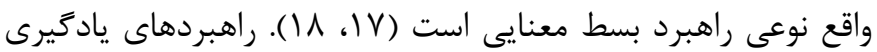


آزمايش و كنترل قرار گرفتند (هر گروه ها نفر). معيار هاى ورود عبارت بود از: دختر بودن، قرار داشتن در پايه اول دوره متوسطه دوم، ترفتن نمره بالاى •r در برسشنامه اهمال كارى تحصيلى، اعلام رضايت براى داى حضور در جلسات و ملاك هاى خروج عبارت بود از: شركت همزمان و

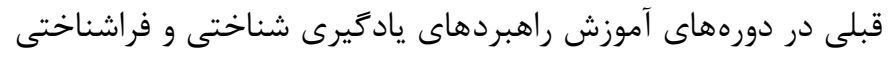

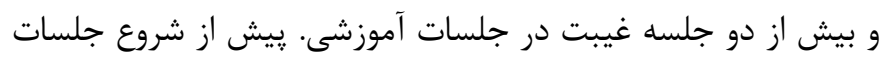

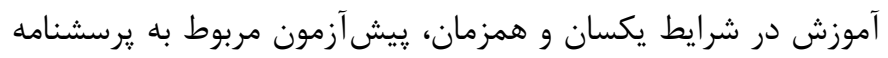

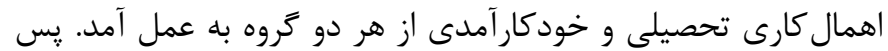
از آن دانش آموزان گروه آزمايش با استفاده از بسته آموزشى راهبردهاى يادكيرى شناختى و فراشناختى كرمى و همكاران (rT) تحت آموزش راهبردهاى يادگيرى شناختى و فراشناختى قرار گرفتند. جلسات آموزشى طى 1 جلسه •9 دقيقهاى و هر هفته يكى جلسه بركزار شد.

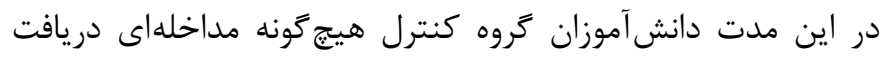

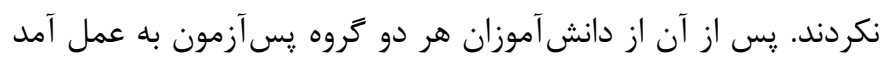

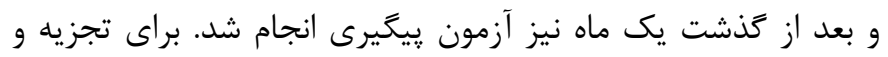

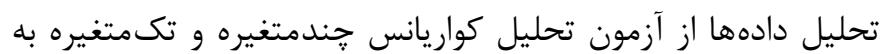
وسيله از نرمافزار SPSS-18 استفاده شد.
و موفقيتآميز طراحى كرده و از انحرافات احتمالى در برنامهريزى هاى درازمدت خود بكاهند. با توجه به نقشى كه دانشآموزان در يادكيرى

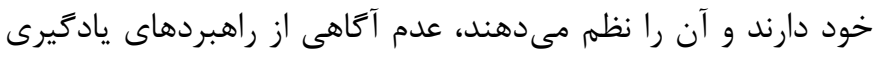

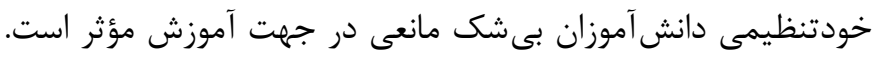

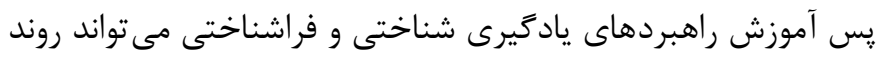

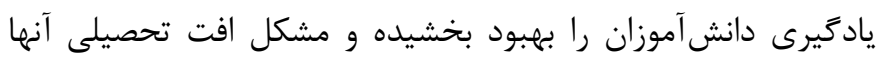

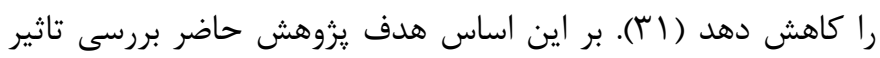

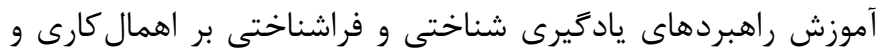

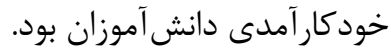

\section{روش كار}

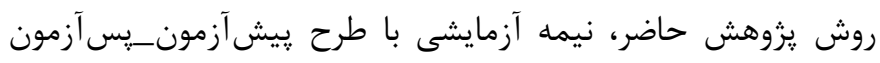

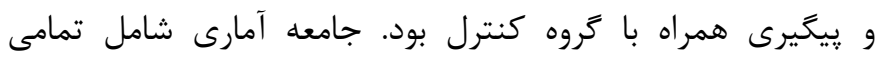

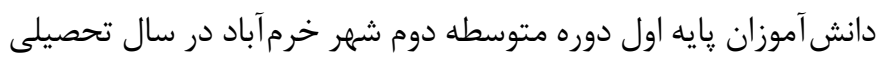
هابه

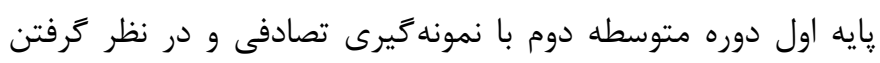
ملاك هاى ورود و خروج انتخاب شدند و به صورت تصادفى در دو كروه

جدول ا. خلاصه جلسات آموزش راهبردهاى يادكيرى شناختى و فراشناختى

\section{خلاصه محتواى جلسات}

جلسات

\begin{tabular}{|c|c|}
\hline 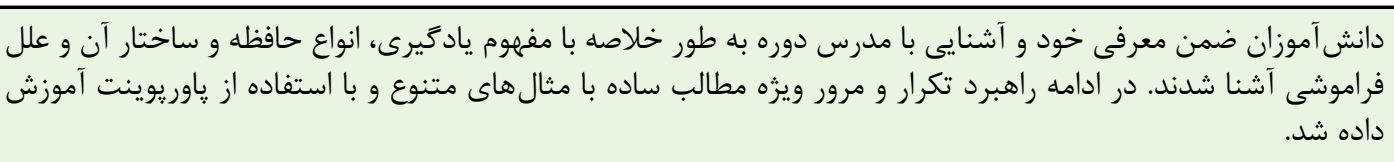 & اول \\
\hline و روش روش راهبرد تكرار ويزه موضوعهاى بيجيده و راهبردهاى كلمه كليدى، سروازه، تصويرسازى ذهنى، استفاده از واسطهها & 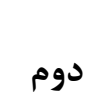 \\
\hline آموزش راهبردهاى كسترش ويزه مطالب يِيجيده مثل يادداشتبردارى، خلاصه كردن، بازكو كردن مطالب به زبان خود & سوم \\
\hline آموزش شرح و تفسير و تحليل روابط، استفاده از اطلاعات آموختهشهه براى حل مسائل، قياس گرى به شيوه جلسات قبل & جهمارم \\
\hline 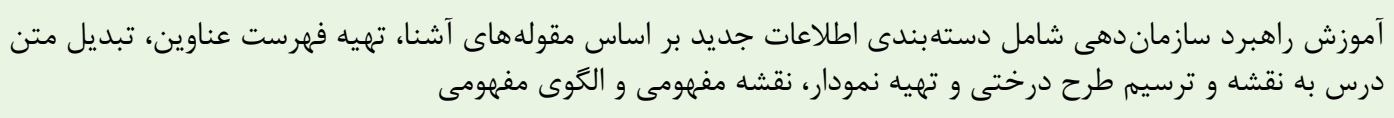 & 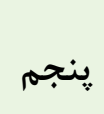 \\
\hline 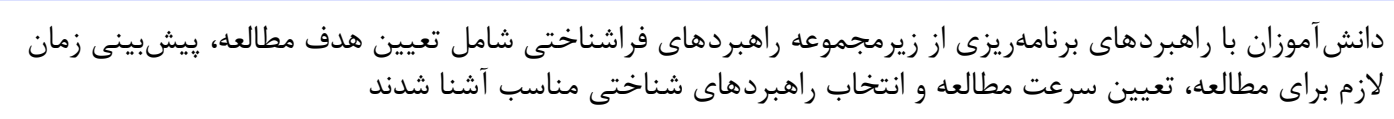 & ششم \\
\hline و طرح سؤال در زمان نطارالعه وارزشيابى از زيرمجموعه راهبردهاى فراشناختى شامل ارزشيابى از پيشرفت، نظارت بر توجه & هفتم \\
\hline مربوط به خطاها راهماى نظمدهى شامل ساز كارى هاى فراشناختى يايدار و بجسازىهايى كه از سوى يادَيرنده در برابر بازخوردهاى & هشتم \\
\hline
\end{tabular}


آزمايش و كنترل در شرايط پِيشآزمون، پِ آزمون و پِيگيرى نشان داده شده است. همانطور كه مشاهده مىشود ميانگين نمره كل

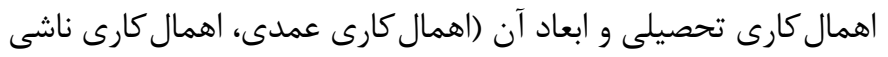

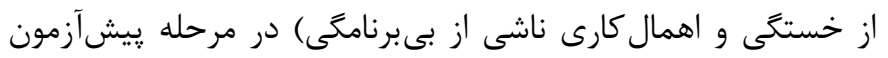

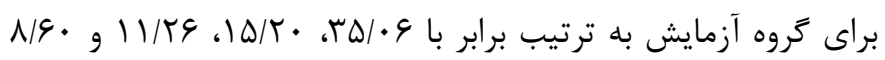

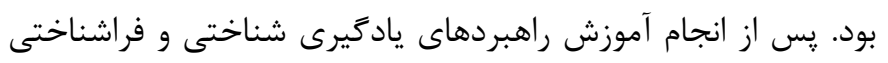

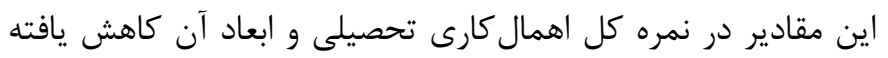

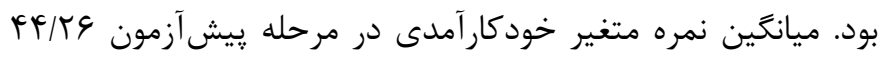
بود كه يس از انجام آموزش راهبردهاى يادكيرى شناختى و فراشناختى

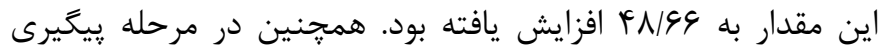
در كروه آزمايش نمره كل اهمال كارى تحصيلى و ابعاد آن نسبت به مرحله بِيشآزمون كاهش يافته بود. از طرفى در مرحله بِيخيرى نمره

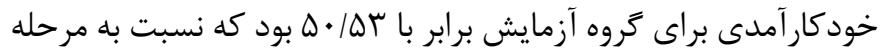

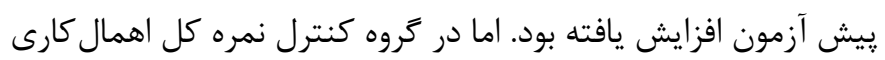

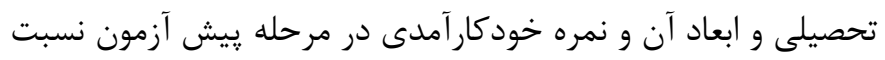

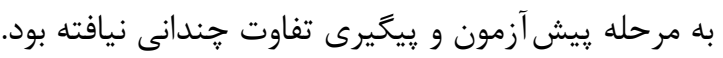

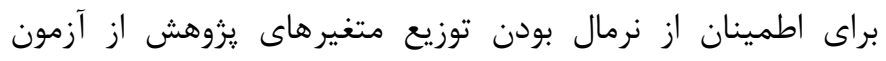
كولموكروف_اسميرنف استفاده شد. نتايج اين آزمون در هر يك

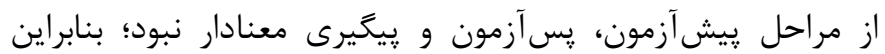
توزيع دادها نرمال بود. براى بررسى همخنى واريانس متغيرهاى

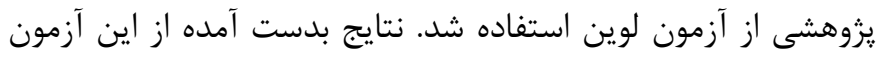

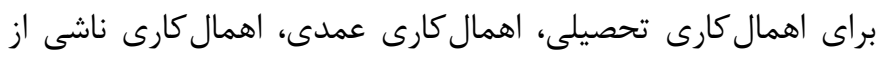

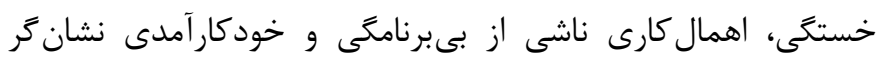

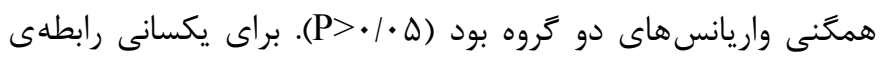

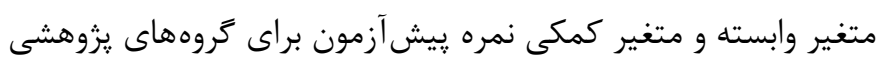

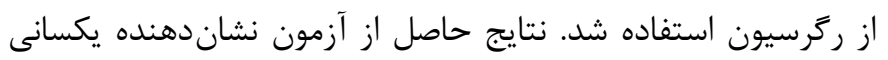

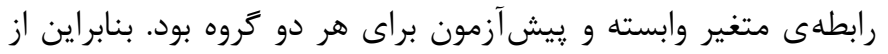
تحليل كواريانس جندمتغيره و تكمتغيره براى تحليل آمارى استفاده شد كه نتايج آن را در جدول بَ ارائه شده است.

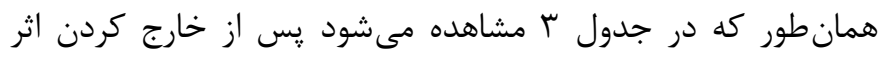

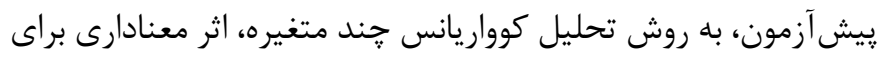

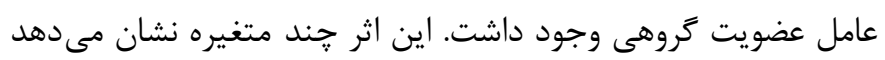
كه آموزش راهبردهاى يادخيرى خودتنظيمى بر اهمال كارى تحصيلى دانشآموزان تأثير دارد. به منظور تعيين اين كه در كدام يك از ابعاد

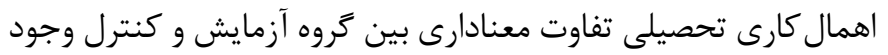
دارد از آزمون تحليل كوواريانس تكمتغيره استفاده شد كه نتايج آن در جدول ^ ارائه گرديده است.

\section{يرسشنامه اهمال كارى تحصيلى (Academic Procrastination} Questionnaire): براى سنجش اهمال كارى تحصيلى از يرسشنامه

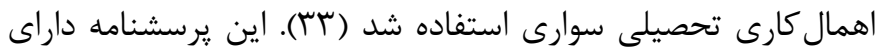

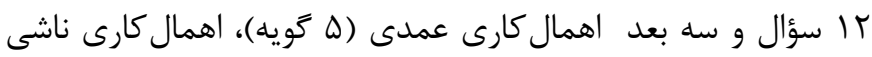

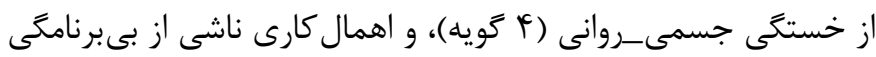

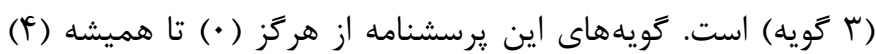

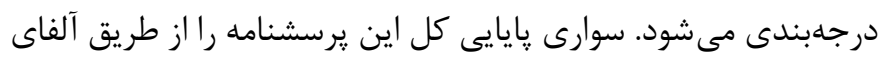

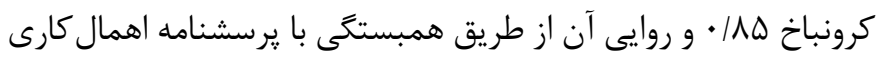
Tukman يرسشنامه است. همجنين وى همسانى درونى ابعاد يرسشنامه را براى

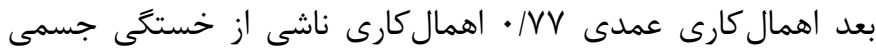

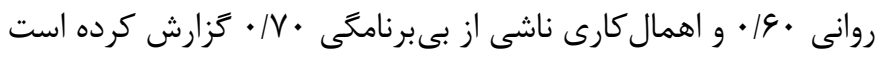

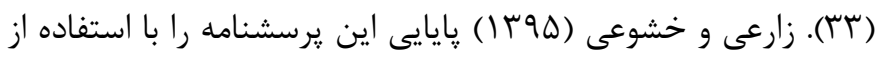

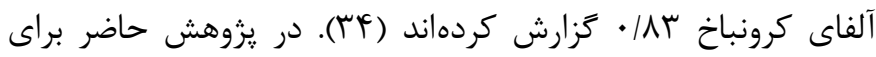

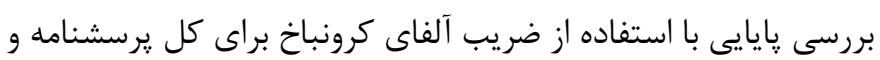

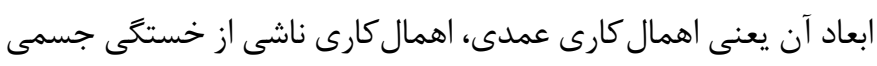

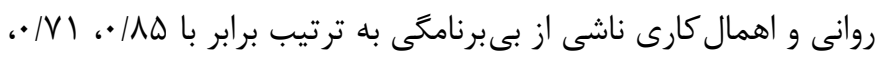

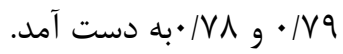

يرسشنامه خودكار آمدى عمومى (General Self-efficacy Scale):

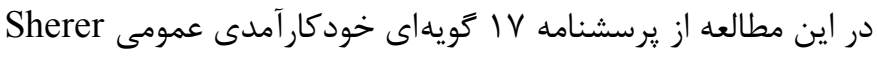
و Maddux استفاده شد كه كويهها از كاملاً مخالفم (1) تا كاملاً

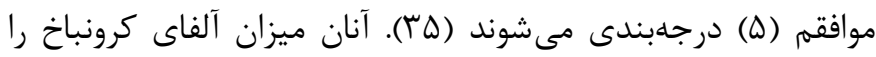

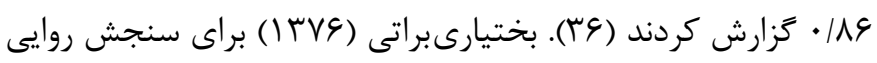

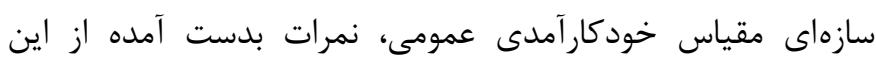

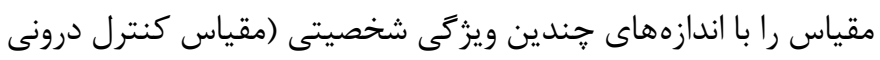

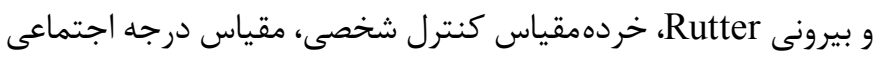
Marlowe-Crowne و مقياس شايستگى بين فردى Rosenberg ) همبسته كرد كه همبستخى بيشبينى شده بين مقياس خودكارآمدى و اندازههاى خصوصيات شخصيتى متوسط | |9|• و در جهت تاييد سازه

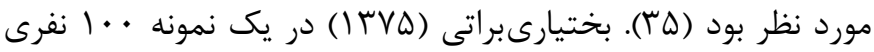

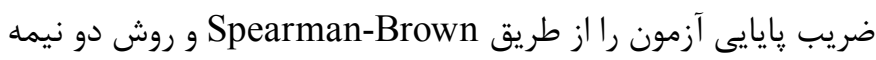

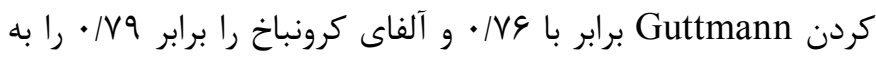

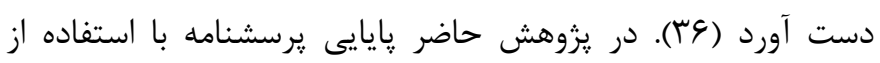

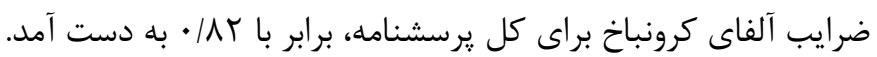

يافته ها در جدول r شاخص هاى توصيفى (ميانگَن و انحراف معيار) دو كروه 
جدول ז. شاخصهاى توصيفى نمرات اهمال كارى تحصيلى و خودكارآمدى آزمودنىها برحسب مرحله و عضويت گروهى
بيكيرى
يس آزمون
بيش آزمون

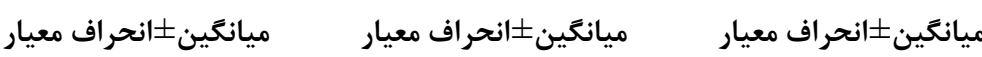

كروه

\begin{tabular}{|c|c|c|c|c|}
\hline$r / \mathcal{R} \pm r q / / r$ & $\Delta r / r q \pm \Delta \Delta / r$ & $. \varphi / r \Delta \pm \varepsilon \wedge / r$ & اهمال كارى تحصيلى & \multirow{5}{*}{ حروه آزمايش } \\
\hline $1 / r F \pm I T / I r$ & $r \cdot / l r \pm \mid N / l$ & $r \cdot|| \Delta \pm \varepsilon|/|$ & اهمال كارى عمدى & \\
\hline $1 / \cdot r \pm 9 / V r$ & $\Lambda \cdot / 9 \pm 1 f / 1$ & $r \varphi / \| \pm r \wedge / 1$ & اهمال كارى ناث & \\
\hline $1 / r \pm V / r \varepsilon$ & $r r / V \pm I 1 / l$ & $\varepsilon \cdot|\Lambda \pm| \Lambda / 1$ & اهمال كارى ناشـ & \\
\hline$r / 9 r \pm \Delta \cdot / \Delta r$ & $\varepsilon \varphi / F \wedge \pm V V / \Gamma$ & $r \varepsilon / \mathcal{F} \pm \pm \mid \varepsilon / \mathcal{F}$ & خودكار & \\
\hline r & $৭ \varphi / / \varphi \pm 9 q / r$ & $19 / T \varphi \pm q V / T$ & اهمال كارى & \multirow{5}{*}{ گروه كنترل } \\
\hline $.9 / \mid \Delta \pm q ৭ /$. & $\wedge \varepsilon / \mid \uparrow \pm \wedge r /$. & $r \cdot\|r \pm r r /\|$ & اهمال كارى عمدى & \\
\hline$q \cdot / 1 r \pm 91 / 1$ & $\Delta r / / r \pm \Lambda \Lambda / 1$ & $|r /| r \pm 19 / r$ & اهمال كارى نان & \\
\hline $1 / / r \pm 1 \cdot / 1 r$ & $\cdot 9 / 1 \cdot \pm \cdot r / 1$ & Gr/Q $\pm r N / I$ & اهمال كارى ناشى از بى برنامعى & \\
\hline G/GG士FF/TH & $\mid r / F F \pm q r / 9$ & $1 \varepsilon / \uparrow q \pm 19 / 9$ & خودكار آمدى & \\
\hline
\end{tabular}

جدول r. نتايج تحليل كوواريانس جندمتغيره در مراحل بِس آزمون و بِيخيرى

\begin{tabular}{|c|c|c|c|c|c|}
\hline $\mathbf{P}$ & $\mathbf{F}$ & درجه آزادى خطا & & آزمون & \\
\hline $.1 \cdot .1$ & $\mid \Delta / \cdot V$ & $r \cdot 1 \cdot$. & $\cdot|\Lambda|$ & بيلايى & \multirow{4}{*}{ كروه } \\
\hline$\cdot 1 \cdot \cdot 1$ & $|Q| \cdot V$ & $r \cdot 1 \cdot$. & $\cdot 111$ & لامبداى ويلكز & \\
\hline$\cdot 1 \cdot .1$ & $|\Delta| \cdot V$ & $r \cdot / \cdot$ & $F / \Delta T$ & هتلينَ & \\
\hline $.1 \cdot .1$ & $|\Delta| \cdot V$ & $r \cdot 1 \cdot$. & F/QT & بزركترين ريشه روى & \\
\hline
\end{tabular}


در متغير خودكارآمدى را نشان مىدهد. همان گونه كه در جدول مشاهده مىشود، بين آزمودنى هاى كروههاى آزمايش و كنترل تفاوت

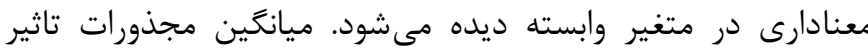

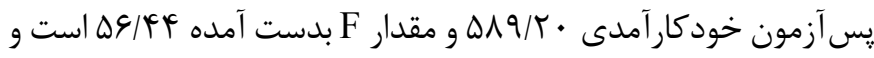

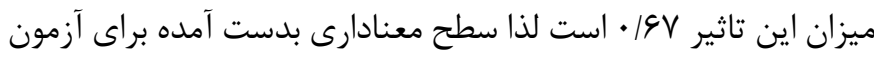

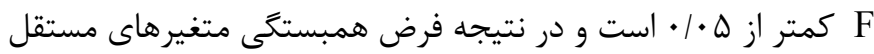
و همبراش تاييد شد. همجنين ميانخين مجذورات عضويت گروهى آنى 

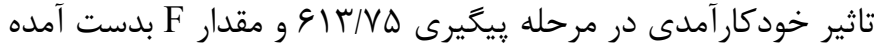

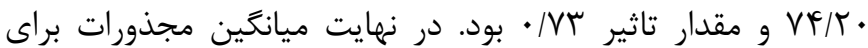

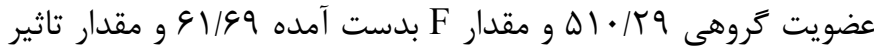
اتا 99/ • بود. با توجه به مطالب كفتته شده آموزش راهبردهاى يادكيرى شناختى و فراشناختى توانسته است به طور معنادارى در افزايش

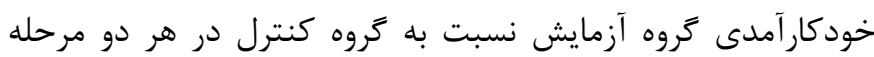

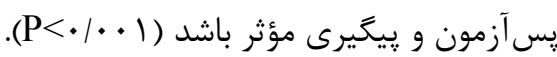

جدول f ا نتايج مربوط به تحليل كوواريانس يافتهاى يزوهش را نشان مى دهد. همان كونه كه مشاهده مىشود، بين آزمودنىهاى كروههاى

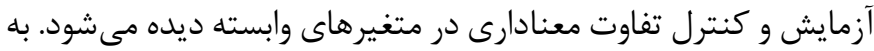
كونهاى كه آموزش راهبردهاى يادگيرى شناختى و فراشناختى توانسته

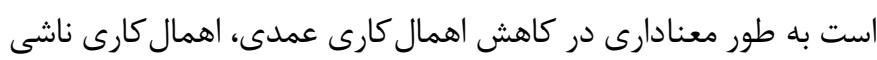

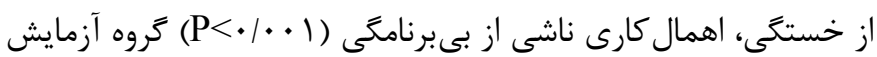

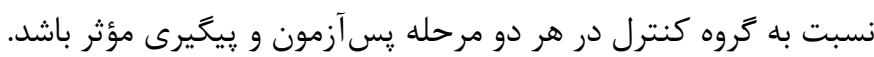

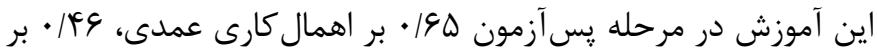

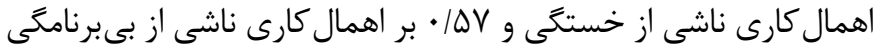

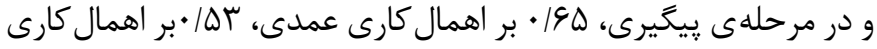

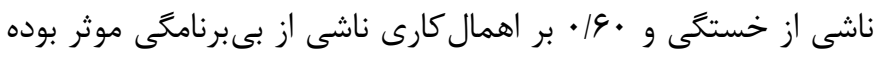

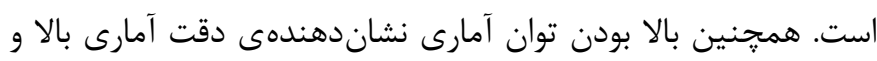

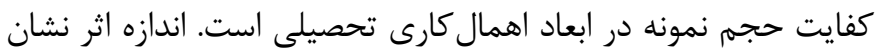
مى دهد مداخله مورد نظر يس از كذشت يكى ماه ماندكار بوده است.

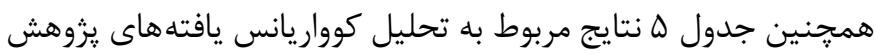

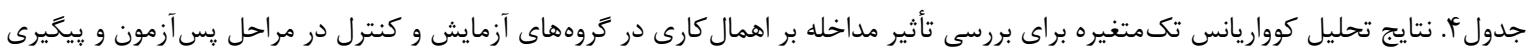

\begin{tabular}{|c|c|c|c|c|c|c|c|c|}
\hline آمارى & مجذور & $\mathrm{P}$ & $\mathrm{F}$ & مجذانغين & آزادى درجه & مجذور هاع & متغير & منبع تغييرات \\
\hline$\cdot / \Lambda$ & $\cdot / T \Delta$ & $\cdot / \cdot v$ & $N / D \mid$ & $\Delta / 99$ & 1 & $\Delta / 99$ & اهمال كارى عمدى & \multirow{3}{*}{ 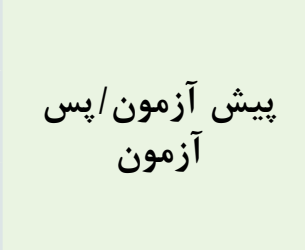 } \\
\hline $1 / \cdot$ & $\cdot|9|$ & $.1 \cdot .1$ & rq/rd & $4 \cdot 190$ & 1 & $r \cdot 190$ & اهمال كارى ناشى از خستخى & \\
\hline$\cdot|\Lambda|$ & . /4 & $.1 \cdot .4$ & N/AF & $\Lambda / \cdot \Lambda$ & 1 & $\Lambda / \cdot \Lambda$ & اهمال كارى ناشى از بى برنامكى & \\
\hline $1 / \cdot$ & $\cdot 190$ & $.1 \cdot .1$ & FN/TL & rT/Tr & 1 & Tr/T & ا اهمال كارى عمدى & \multirow{3}{*}{ عضويت تروهى } \\
\hline.$/ 99$ & $\cdot / 44$ & $.1 . .1$ & $r / / \wedge q$ & $r T / G \mid$ & 1 & $r T / 91$ & اهمال كارى ناشى از خستكى & \\
\hline $1 / \cdot$ & $\cdot / \Delta \mathrm{V}$ & $.1 . .1$ & 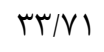 & $r \cdot / \Lambda T$ & 1 & $r \cdot \mid \Lambda r$ & اهمال كارى ناشى از بى برنامكى & \\
\hline$\cdot / \Delta \Lambda$ & $\cdot / / \mathrm{V}$ & $\cdot / \cdot r$ & $\Delta / / Q$ & $0 / .4$ & 1 & $\Delta / \cdot 4$ & اهمال كارى عمدى & \multirow{3}{*}{ ييش آزمون / پيخيرى } \\
\hline $1 / \cdot \cdot$ & .191 & $.1 \cdot .1$ & $\Delta F / V$. & $\mid F+1.4$ & 1 & $|\psi| \cdot \varphi$ & اهمال كارى ناشى از خستكى & \\
\hline.$/ 91$ & $\cdot|4|$ & $.1 . .1$ & $\mid V / q Y$ & $1 r / 49$ & 1 & $1 r / 4 q$ & اهمال كارى ناشى از بى برنامكى & \\
\hline $1 / \cdot$ & .190 & $.1 \cdot .1$ & $4 N / \cdot q$ & $\notin V / T \Delta$ & 1 & FV/TD & الهمال كارى عمدى & \multirow{3}{*}{ عضويت كروهى } \\
\hline.$/ 99$ & • & $.1 . .1$ & TN/99 & $r \mu / \cdot q$ & 1 & $r \mu / \cdot 9$ & اهمال كارى ناشى از خستتى & \\
\hline $1 / \cdot \cdot$ & .19 & $.1 \cdot .1$ & rN/Al & $r q / / \Lambda$ & 1 & $r q / 11$ & اهمال كارى ناشى از بى برنامكى & \\
\hline
\end{tabular}


جدول ه. نتايج تحليل كوواريانس تكمتغيره براى بررسى تأثير مداخله بر خودكارآمدى در گروههاى آزمايش و كنترل در مراحل يس آزمون و پِيخيرى

\begin{tabular}{|c|c|c|c|c|c|c|c|c|}
\hline توان & مجذور & $\mathrm{P}$ & $\mathrm{F}$ & مجذانغين & آزادى درجه & مجذورهاع & متغير & منبع تغييرات \\
\hline $1 / \cdot$ & $\cdot 19 \mathrm{~V}$ & $\cdot 1 \cdot .1$ & $\Delta G / F Y$ & $\Delta \wedge 9 / r$. & 1 & $\Delta \wedge 9 / \%$. & خودكار آمدى & پِيش آزمون / يس آزمون \\
\hline $1 / \cdot$ & • & $\cdot 1 \cdot .1$ & $r / / \Lambda$ & TTQ/DV & 1 & TYQ/DV & خودكار آمدى & عضويت گروهى \\
\hline $1 / \cdot$ & $\cdot / V T$ & $.1 \cdot .1$ & $V F / T$. & SIr/VD & 1 & SIr/VD & خودكار آمدى & بيش آزمون/ِيكيرى \\
\hline $1 / \cdot$ & $\cdot 199$ & $.1 \cdot .1$ & $91 / 99$ & $\Delta 1 \cdot / \pi q$ & 1 & $\Delta 1 \cdot / r q$ & خودكار آمدى & عضويت گروهى \\
\hline
\end{tabular}

نتايج يزوهش حاضر نيز نشان داد كه آموزش راهبردهاى يادكيرى شناختى و فراشناختى باعث كاهش اهمال كارى دانش آموزان مى شود كه يزوهشهاى ييشين تاييدى بر اين يافته است (V، ^). نتايج يزوهش حاضر نشان داد كه آموزش راهبردهاى يادگيرى شناختى و فراشناختى باعث افزايش خودكارآمدى دانشآموزان شده است. Zimmerman ور مطالعهاى دريافتند كه يكى از علل مههم نبود موفقيت تحصيلى، خودكارآمدى پايين است. آنان دريافتند

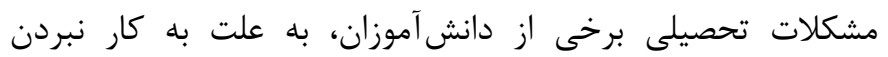

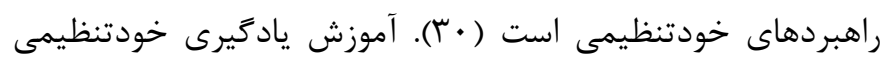
با به كاركيرى راهبردهاى شناختى و فراشناختى مناسب، سعى در

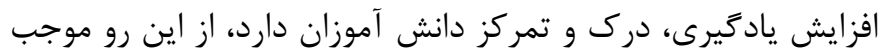
بهبود عملكرد دانش آموزان مى كردد، در نتيجه اضطراب دانش آموزان كاهش و موجب افزايش خودكارآمدى خواهد شد. بنابراين آموزش راهبردهاى يادگيرى شناختى و فراشناختى با به كار بردن راهبردهاى

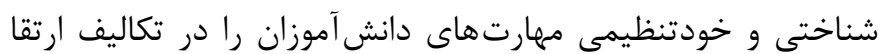
داده، موجب مى شود كه دانش آموزان، تكاليف درسى و مسائل مربوط

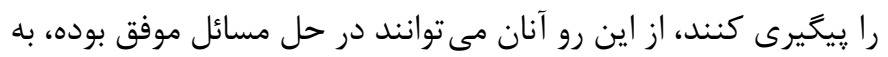

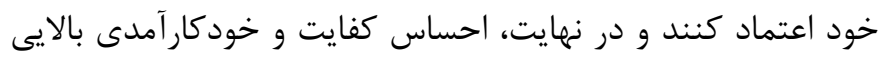

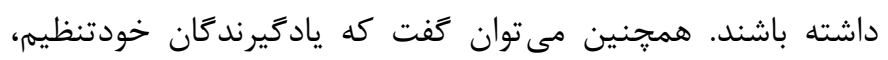
مشاركت كنندًان فعال در فرايند يادكيرى هستند. اين دانشآموزان براى پيخيرى اهداف يادگيرى خود از راهبردهاى يادَيرى گوناگون استفاده مى كنند و به طور مداوم بر ويشرفت خود نظارت دارند. يادگيرندكان خودتنظيم در تلاش براى يادَيرى اصرار مىورزند و در صورت لزوم به منظور يادگيرى بهتر، راهبردهاى خود را تغيير براي
هدف يروهش حاضر، بررسى تأثير آموزش راهبردهاى يادكيرى شناختى في و فراشناختى بر اهمال كارى تحصيلى و خودكارآمدى دانشآموزان تردي بود. بر اساس نتايج يزوهش، آموزش راهبردهاى يادگيرى شناختى و فراشناختى باعث به طور معنادارى باعث كاهش اهمال كارى تحصيلى

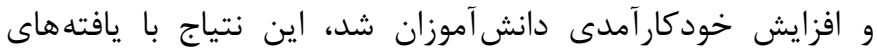

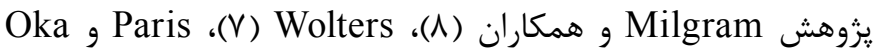

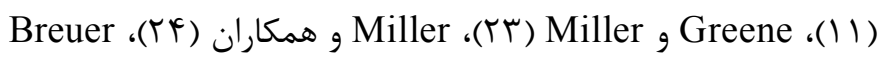

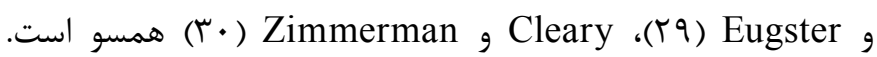
يافته هاى تحقيقاتى نشان مى دهد كه آن دسته از فراگيرانى كه از

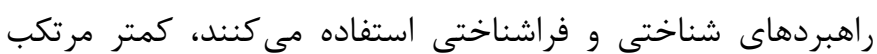
اهمال كارى مى شوند (N). Wolters در يزوهش خود نشان مى دهد كه افرادى كه داراى اهداف تبحرى_رويكردى هستند، وظايفشان را به

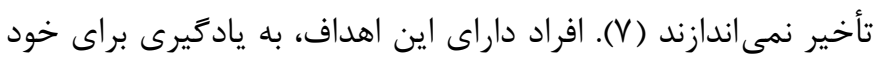

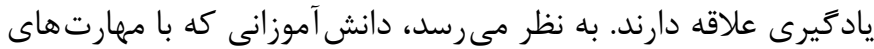
فراشناختى و كنترل شرايط يادگيرى، بر عملكرد خود نظارت

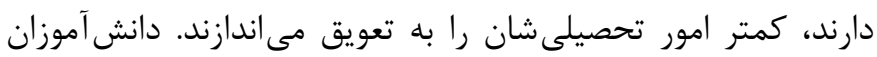

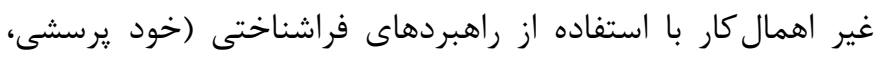

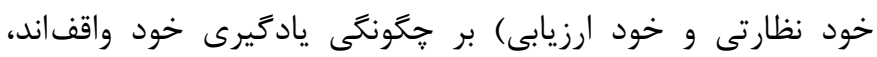

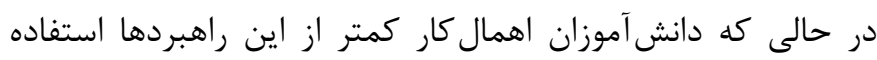
مى كنند. اين يافته نيز همسو با يافته هاى يُيشين است. Wolters

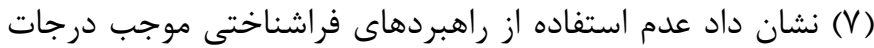
بالايى از اهمال كارى در دانش آموزان مى شود. همجنين رowell و Watson توسط دانشآموزان، اهمال كارى را در آنان كاهش مى دهد (YV). 


\section{نتيجه كَيرى}

يِينهاد مىشود با توجه به تاثير تذارى آموزش راهبردهاى شناختى

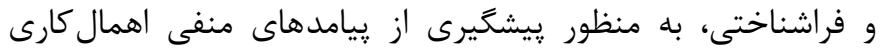

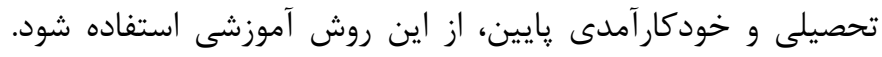

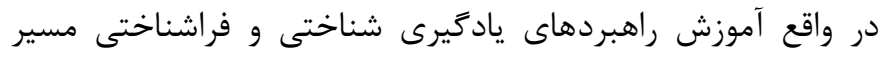

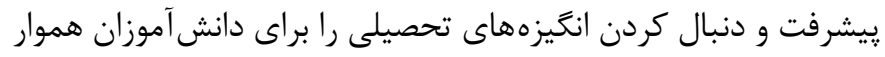

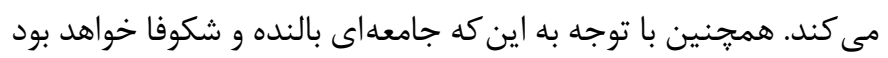

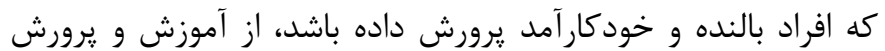
انتظار مىرود برنامهاى تربيتى تدوين نمايد كه هدف آن خودنظهم

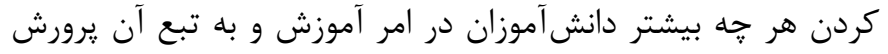
انسان هايى كارآمد، مسئول، مستقل و داراى معيارهاى درونى باشد.

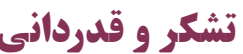

در يايان از مساعدتهاى تمامى عوامل به ويزه مديريت محترم اداره

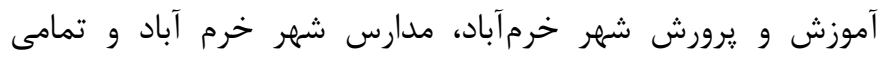

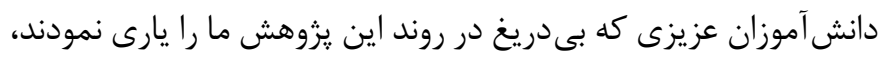
صميمانه سياسگزارى مى خردد.

\section{References}

1. Moon SM, Illingworth AJ. Exploring the dynamic nature of procrastination: A latent growth curve analysis of academic procrastination. Personality and Individual Differences. 2005;38(2):297-309.

2. Kim KR, Seo EH. The relationship between procrastination and academic performance: A meta-analysis. Personality and Individual Differences. 2015;82:26-33.

3. Beswick G, Rothblum ED, Mann L. Psychological antecedents of student procrastination. Australian Psychologist. 1988;23(2):207-217.

4. Senecal C, Koestner R, Vallerand RJ. Self-regulation and academic procrastination. The Journal of Social Psychology. 1995;135(5):607-619.

5. Solomon LJ, Rothblum ED. Academic procrastination: Frequency and cognitive-behavioral correlates. Journal of Counseling Psychology. 1984;31(4):503-509.
مى دهند. دانش آموزانى كه خود را كارآمد مى دانند، از راهبردهاى شناختى و فراشناختى بيشترى استفاده مى كنند و براى انجام تكاليف تلاش بيشترى مىورزند (1). دانش آموزانى كه تحت آموزش قرار گرفتند، متوجه شدند كه جه جِيزى را بايد ياد بخيرند، جه جيزى را بايد مطالعه كنند و بهترين زمان براى تمركز روى تكاليف جهه زمانى است. تمامى عوامل فوق باعث جهت دادئ رادن

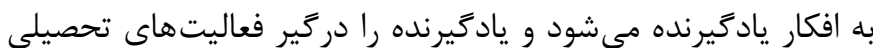
مى كند. همان طور كه Flavell بيان كرده است، آموزش اين راهبردها و فراگيرى آنها توسط ياد گيرند به نفس بيشترى در جلسات امتحان حاضر شوند و در نتيجه يِيشرفت بهترى در عملكرد تحصيلى داشته باشند (19). از جمله محدوديتهاى يزوهش حاضر، محدود بودن نمونهى يزوهش به دانش آموزان خرمآبادى بود و ديكر اين كه اين يزوهش تنها روى ئرى دانشآموزان دختر پايه اول دوره متوسطه دوم صورت گرفته است. بنابراين ريشنهاد مى شود اين يزوهش با حضور دانش آموزان رِّر و

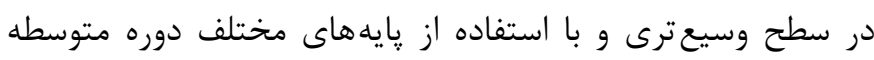

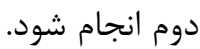

6. Steel P. The nature of procrastination: A meta-analytic and theoretical review of quintessential self-regulatory failure. $P s y$ chological bulletin. 2007;133(1):65-94.

7. Wolters CA. Understanding procrastination from a self-regulated learning perspective. Journal of Educational Psychology. 2003;95(1):179-187.

8. Milgram NA, Sroloff B, Rosenbaum M. The procrastination of everyday life. Journal of Research in Personality. 1988;22(2):197-212.

9. Bandura A. Self-efficacy: toward a unifying theory of behavioral change. Psychological Review. 1977;84(2):191-215.

10. Nikos M, George P. "Student's motivational beliefs, self-regulation use, and mathematics achievement". In Proceedings of the 29th Conference of the International Group for the Psychology of Mathematics Education; 2005 July 10-15; Melbourne, Australia. 
11. Paris SG, Oka ER. Children's reading strategies, metacognition, and motivation. Developmental Review. 1986;6(1):25-56.

12. Ross M, Perkins H, Bodey K. Academic motivation and information literacy self-efficacy: The importance of a simple desire to know. Library \& Information Science Research. 2016;38(1):2-9.

13. Fattahi SH. The influence of teaching management and time-scheduling (self-regulatory) skills on achievementmotivation and academic performance of secondary school students in basic science courses. [MS Thesis]. Birjand:Birjand University;2010. (Persian)

14. Yang HJ. Factors affecting student burnout and academic achievement in multiple enrollment programs in Taiwan's technical-vocational colleges. International Journal of Educational Development. 2004;24(3):283-301.

15. Lester D, Yang B. Two sources of human irrationality: Cognitive dissonance and brain dysfunction. The Journal of Socio-Economics. 2009;38(4):658-662.

16. McWhaw K, Abrami PC. Student goal orientation and interest: Effects on students' use of self-regulated learning strategies. Contemporary Educational Psychology. 2001;26(3):311-329.

17. Saif AA. Modern educational psychology: Psychology of learning and teaching. Tehran: Douran;2012. (Persian)

18. Schulz M, Roßnagel CS. Informal workplace learning: An exploration of age differences in learning competence. Learning and Instruction. 2010;20(5):383-399.

19. Flavell JM. Metacognitive aspects of problem solving. In Resnic Lb, editor. The nature of intelligence, Hillsdale. New Jersey:Erlbaum;1976. pp. 231-235.

20. Van Der Stel M, Veenman MV. Development of metacognitive skillfulness: A longitudinal study. Learning and Individual Differences. 2010;20(3):220-224.

21. Kim B, Park H, Baek Y. Not just fun, but serious strategies: Using meta-cognitive strategies in game-based learning. Computers \& Education. 2009;52(4):800-810.

22. Hübner S, Nückles M, Renkl A. Writing learning journals: Instructional support to overcome learning-strategy deficits.
Learning and Instruction. 2010;20(1):18-29.

23. Greene BA, Miller RB. Influences on achievement: Goals, perceived ability, and cognitive engagement. Contemporary Educational Psychology. 1996;21(2):181-192.

24. Miller RB, Greene BA, Montalvo GP, Ravindran B, Nichols JD. Engagement in academic work: The role of learning goals, future consequences, pleasing others, and perceived ability. Contemporary Educational Psychology. 1996;21(4):388-422. 25. Schunk DH, DiBenedetto MK. Self-efficacy theory in education. In Wenzel KR, Miele DB, editors. Handbook of motivation at school. 2nd ed. New York:Routledge;2009. pp,34-54. 26. Chularut P, DeBacker TK. The influence of concept mapping on achievement, self-regulation, and self-efficacy in students of English as a second language. Contemporary Educational Psychology. 2004;29(3):248-263.

27. Fortsch P, Henning JE, Nielsen LE. Connecting classroom to clinical practice: A comparison of programs. Radiologic Technology. 2009;81(2):112-121.

28. Haj Shamsaie M, Karshaki H, Amin Yazdi SA. Testing the model of mediator role of self-regulation in relation between classroom socio-mental climate and maladjustment. Journal of School Psychology. 2014;3(3):21-37. (Persian)

29. Breuer K, Eugster B. Effects of training and assessment in vocational education and training (VET): Reflections on the methodology of assessing the development of traits of self-regulation. Studies in Educational Evaluation. 2006;32(3):243-261.

30. Cleary TJ, Zimmerman BJ. Self_regulation empowerment program: A school_based program to enhance self_regulated and self_motivated cycles of student learning. Psychology in the Schools. 2004;41(5):537-550.

31. Motie H, Heidari M, Sadeghi MA. Predicting academic procrastination during self-regulated learning in Iranian first grade high school students. Procedia-Social and Behavioral Sciences. 2012;69:2299-2308.

32. Karami B, Karami A, Hashemi N. Effectiveness of cognitive and metacognitive strategies training on creativity, 
achievement motive and academic self-concept. Quarterly Journal of Innovation and creativity in the human Sciences. 2014;2(4):121-137. (Persian)

33. Savari K. Construction and standardization of Academic procrastination test. Educational Measurement. 2011;2(5):1-15. (Persian)

34. Zarei L, Khoshoei MS. Relationship of academic procrastination with metacognitive beliefs, emotion regulation and tolerance of ambiguity in university students. Quarterly Journal of Research and Planning in Higher Education. 2016;22(3):113-130. (Persian)
35. Keramati H, Shahr-Arai M. Investigating the relationship between self-perceived efficacy and performance on mathematics among junior high school students. Quarterly Journal of Educational Innovations. 2004;3(10):103-116. (Persian)

36. Foladchang M. Investigating the effect of self-management skills training and increasing self-esteem beliefs on academic performance of high school students. [PhD Dissertation]. Shiraz:Shiraz University;2004. (Persian)

37. Howell AJ, Watson DC. Procrastination: Associations with achievement goal orientation and learning strategies. Personality and Individual Differences. 2007;43(1):167-178. 